\title{
Errata
}

To the paper

\section{ANALYTICAL APPLICATIONS OF NEOTRIDECANOHYDROXAMKC \\ ACID AS STATIONARY PHASE IN EXTRACTION CHROMATOGRAPHY}

\author{
A. Delle Stre
}

J. Radioanal. Chem. Vol. 14 (1973) No. 1, 45-51.

On page 45 , in the title neotridecanohydroxamin should read neotridecanohydroxamic, in the line 7 neotridecanohxdroxamic should read neotridecanohydroxamic.

On page 46, in the line 23 plutonium should read platinum, in the line 29 solutions already been reported should read solutions have already been reported.

On page 47 , in the line $91 \mathrm{M}$ should read $2 \mathrm{M}$.

On page 49 , in the line 4 (12 vol.) should read (120 vol.), in the line 7 percipitate should read precipitate.

On page 50, in the line 17 determination should read decontamination, in the line 30 auther should read author. 